\title{
Characterization of materials used in the execution of historic oil paintings by XRD, SEM-EDS, TGA and LIBS analysis
}

\author{
Kerem Şerifaki ${ }^{a}$, Hasan Böke ${ }^{a, *}$, Şerife Yalçın ${ }^{b}$, Başak Ipekoğlu ${ }^{a}$ \\ ${ }^{a}$ Architectural Restoration Department, İmir Institute of Technology, 35430 Izmir, Turkey \\ ${ }^{\mathrm{b}}$ Chemistry Department, İzmir Institute of Technology, 35430 İzmir, Turkey
}

\section{A R T I C L E D A T A}

Article history:

Received 21 May 2008

Accepted 29 September 2008

Keywords:

Wall paintings

Oil

Pigments

Anglesite

Zinc oxide

\begin{abstract}
A B S T R A C T
In this study, material characteristics of historic oil paintings in a 19th century church in Ayvalı/Turkey were investigated to propose the treatments to be used in their conservation and protection. For this purpose, physical, chemical and mineralogical compositions and the microstructure of the paintings were determined by X-ray Diffraction, Scanning Electron Microscope, Thermo Gravimetric Analyzer, Differential Scanning Calorimeter, Infrared Spectroscopy and Laser Induced Breakdown Spectroscopy. Analysis results showed that the paintings were composed of very thin binding and white priming layers on which the pigments were applied. Binding layers were composed of polymerized vegetable oil with Zinc Oxide. Priming layers were composed of anglesite mineral in polymerized vegetable oil. Pigments used in paintings were mainly green earth, red chrome and iron oxide.
\end{abstract}

(c) 2008 Elsevier Inc. All rights reserved.

\section{Introduction}

Wall paintings have been the most important decorative pieces of historic buildings since ancient times. They can be classified as fresco or secco according to application technique of pigments on the plaster layer. Paintings executed in fresco technique, pigments are applied onto wet plaster and they are fixed during the carbonization of lime. In secco technique, pigments are applied on dry lime plaster with binding materials like gum, egg or oils. Secco technique is named to the used binding materials. If the binder is vegetable gum or animal glue, it is called tempera [1]. If the binder is egg, it is called egg tempera [1]. If the binder is vegetable oil it is called oil painting [1]. Walnut, poppy seed and linseed oils are the most common ones used as binding materials [2]. Vegetable oils are composed of mostly unsaturated fatty acids and solidify in the ambient conditions.

The first stage of the oil painting process is the coating of a fine plaster layer with boiled oil. At this stage, oil penetrates into plaster by capillarity and then solidifies. In the next step, the coated surface is covered with white priming materials dispersed in oils $[1,3]$. The final step of the painting process is the application of pigments to the priming surface [1].

The most common inorganic pigments used in oil paintings are lead white, Naples yellow, azurite, vermilion, verdigris, malachite red, yellow ochre, zinc oxide, cobalt blue and ultramarine [2]. Organic pigments used in traditional oil paintings are indigo, Indian yellow, alizarin, madder, luteolin and quercetin [2,4]. Inorganic pigments are brighter and last longer than organic ones and hence they were used in paintings.

In the recent studies, raw material compositions of paintings and polymerization of vegetable oils have been determined by capillary electrophoresis (CE) [5], micro-Raman spectroscopy [6,7], differential scanning calorimetry (DSC) $[8,9]$ gas chromatography [10] and Laser Induced Breakdown Spectroscopy (LIBS) [11-13].

In this study, the material used in the execution of wall paintings of Taxiarhis Church and the present state of the paintings were determined to decide the appropriate intervention methods and materials to be used in the conservation of the paintings.

Taxiarhis Church was built in the neoclassical style by Architect Emanuel Kounas as the main Church of Cunda/Ayvalık in 1873. It had the basic properties of Byzantine church architecture

\footnotetext{
* Corresponding author. Tel.: +90 232750 7035; fax: +90 2327507012

E-mail address: hasanboke@iyte.edu.tr (H. Böke).
} 
a)

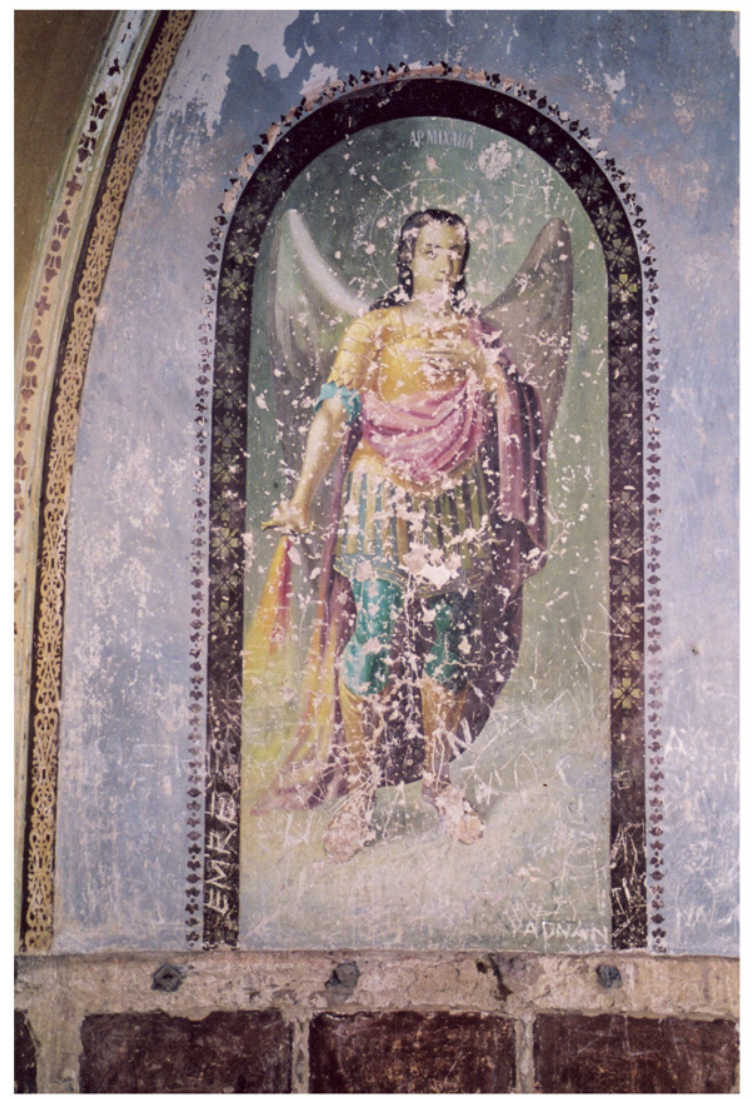

b)

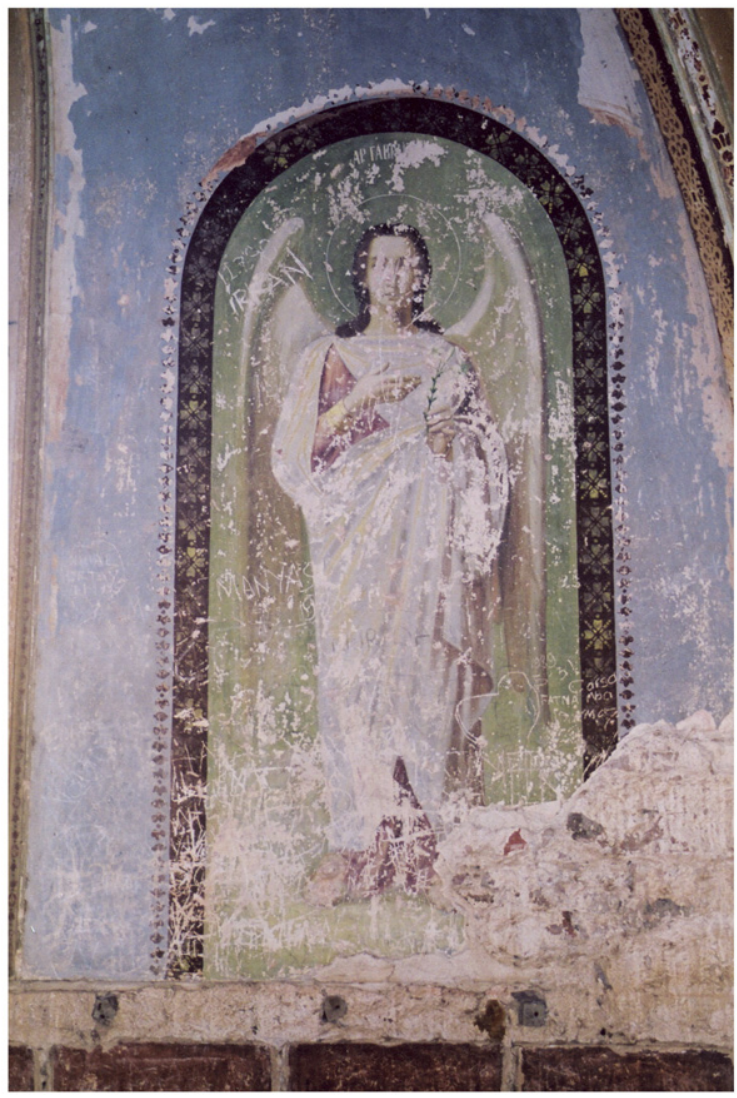

Fig. 1-Michael (a) and Gabriel (b) paintings from the Taxiarhis Church.

although it was built in late period. Taxiarhis Church is a valuable church due to its original wall paintings. Paintings are located on the walls of the main apse, arms of the cross, niches near by the main apse, drum of the central dome and over the doorway on two sides of the narthex. Wall paintings show the events expressed in the Old Testament and Holy Bible (Fig. 1) [14]. Taxiarhis Church suffered structural failures by earthquakes, which occurred in 1942 and 1944. Cracks and the disintegration of

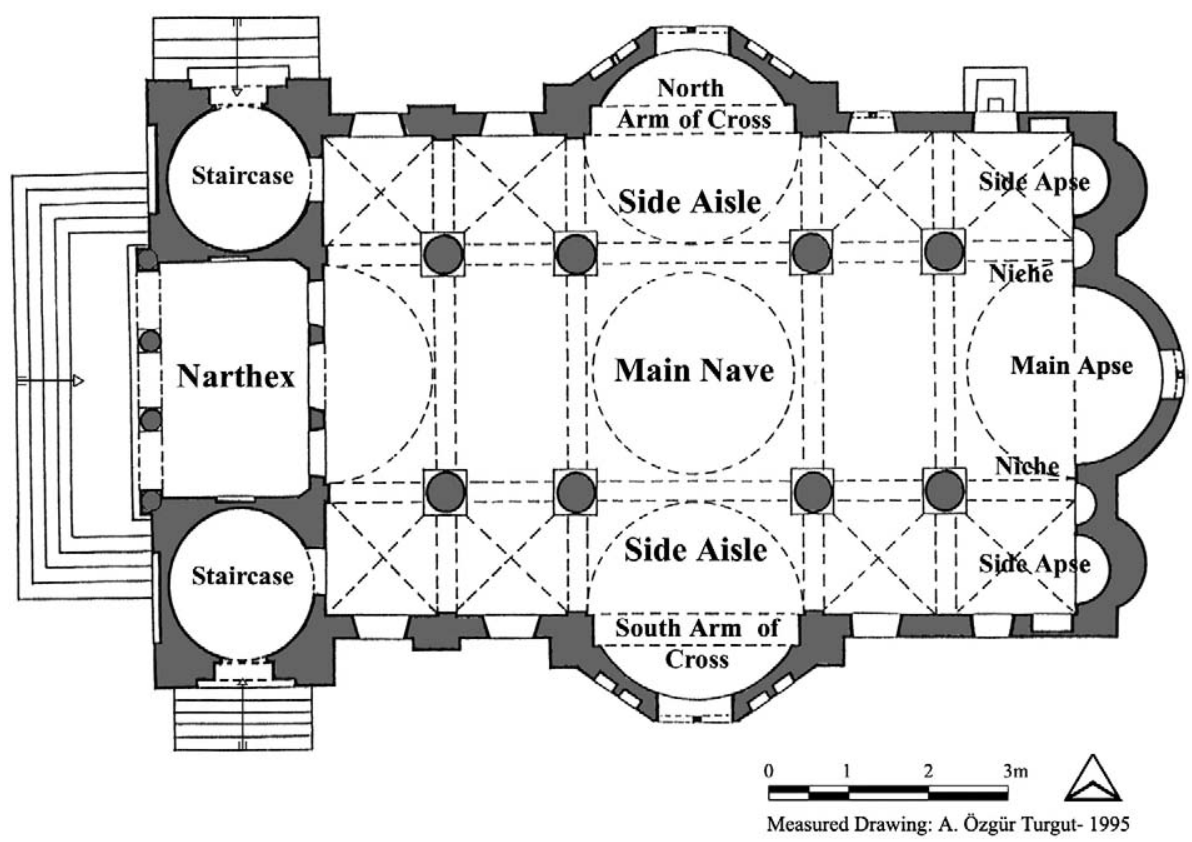

Fig. 2-Plan of Taxiarhis Church. 


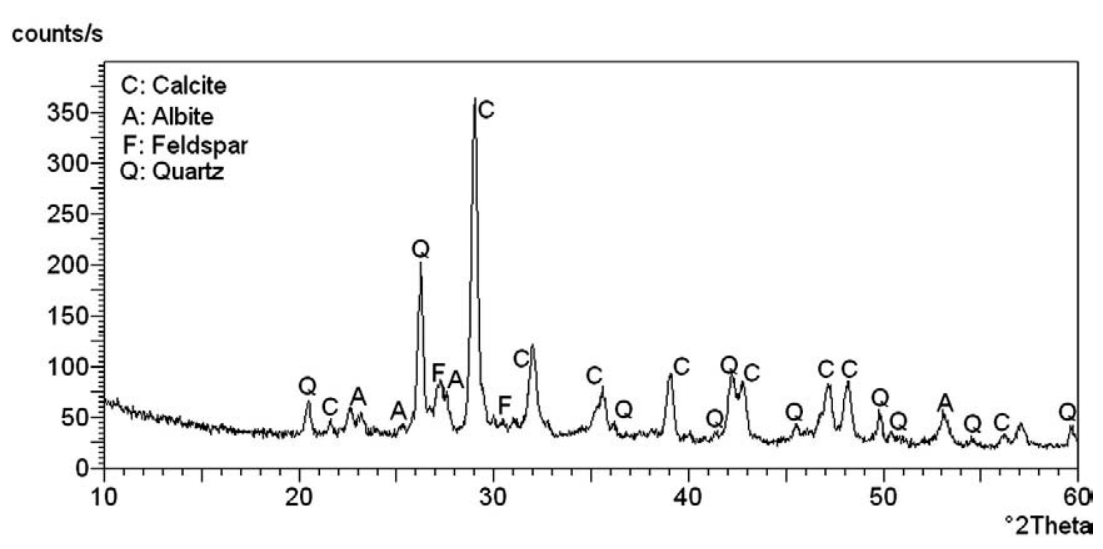

Fig. 3-XRD pattern of rough plaster layer.

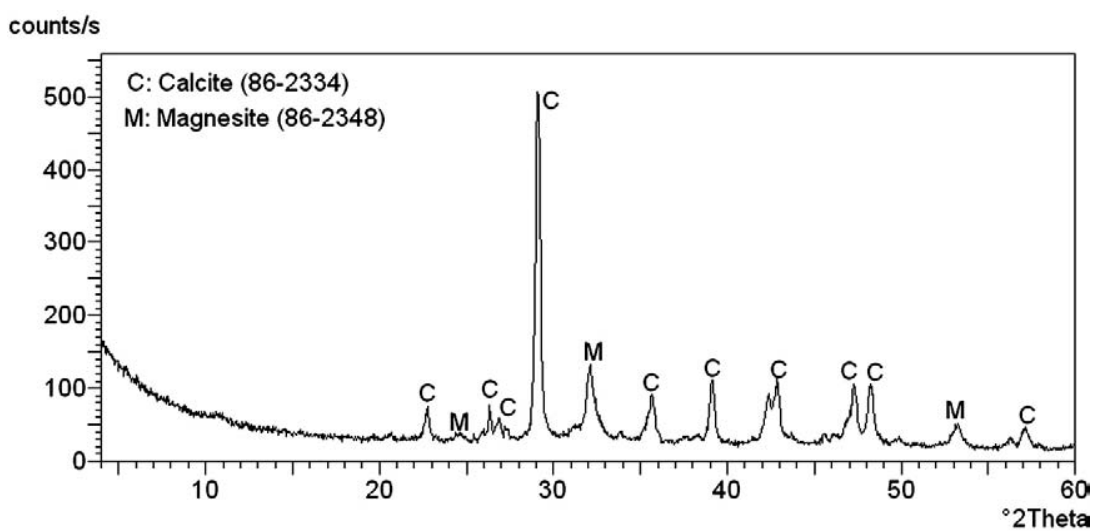

Fig. 4-XRD pattern of fine plaster layer.

the superstructure have allowed rain to penetrate into the church. Rain is the main source of deterioration of the wall paintings. The Church was mentioned in the heritage at risk 2004-2005 report which was published by ICOMOS $^{1}$ due to the structural condition of the building and its wall paintings.

\section{Materials and Methods}

In this study, raw material compositions, basic physical, mineralogical, chemical and micro-structural properties of paintings collected from Taxiarhis Church were determined. Visual deterioration of paintings was also indicated on drawings prepared by using standard software programs.

\subsection{Sampling}

In this study, rough (arriccio) and fine (intonaco) plaster layers and the small amount of brown, red and green painted plaster samples were collected from detached parts of the paintings. Samples were collected from the paintings on the main apse and the north arm of the cross of the church (Fig. 2).

${ }^{1}$ Alexander Zah, TURKEY Churches Built in Ottoman Times, ICOMOS World Report, 2004-2005 on Monuments and Sites in Danger, pp. 245-247. (http://www.international.icomos.org/risk/ 2004/turkey2004.pdf).

\subsection{Characterization of Physical, Chemical and Mineralogical Properties of Plaster Layers}

The bulk densities and porosities, microstructure, chemical and mineralogical compositions of the plaster layers were determined by several laboratory analyses. Bulk densities and porosities of the plaster layers were determined by measuring the dry, water saturated under vacuum and hydrostatic weights [15]. Their mineralogical compositions were determined by X-ray Diffraction (XRD) analyses. Lime and aggregate ratios of the plasters were determined by the dissolution of carbonated lime in dilute hydrochloric acid.

\subsection{Characterization of Microstructural, Chemical and Mineralogical Properties of the Paintings}

Microstructural characteristics and the elemental compositions of the paintings were determined with a Scanning Electron Microscope (SEM) coupled with EDS. SEM analysis results showed that the paintings are composed of a very thin strata of oil binding on the fine plaster and white priming layer on which the pigments were applied. Hence, priming and binding layers together were carefully separated from fine plaster layers under a stereomicroscope, using a small lancet for analysis.

The mineralogical and elemental compositions of the priming layers were determined by X-ray Diffraction (XRD) 


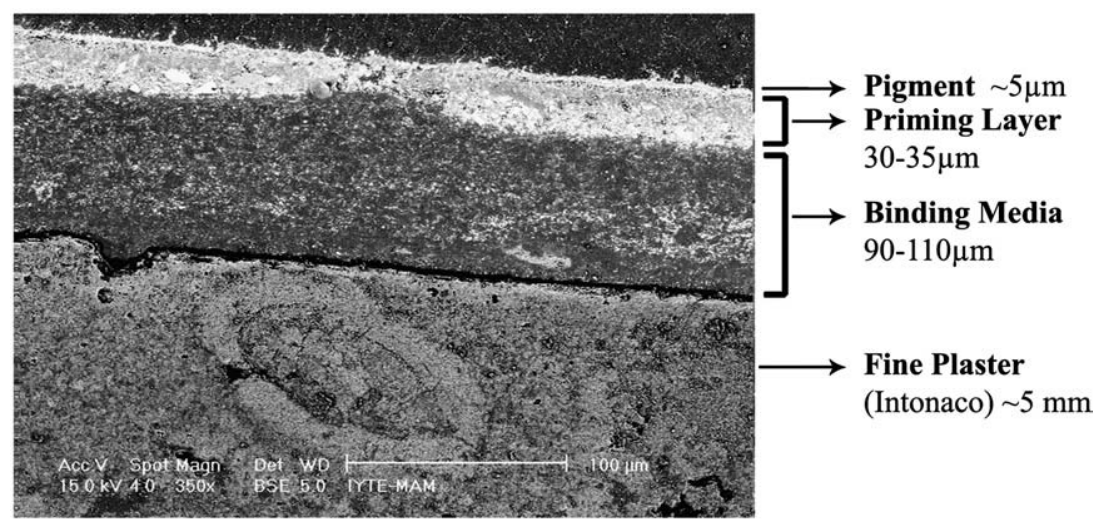

Fig. 5-BSE image of the painting layers.

and SEM analysis. The functional groups in the binding layers were determined by a Fourier Transform Infra-Red (FTIR) spectrometer. Thermo-gravimetric analysis (TGA) was used to determine the weight loss during the heating of the binding media. Analysis was carried out in static nitrogen atmosphere at a temperature range of $30-1000{ }^{\circ} \mathrm{C}$ with a heating rate of $10{ }^{\circ} \mathrm{C} / \mathrm{min}$. In order to determine the melting and decomposition temperatures of the binding media, differential scanning calorimetry (DSC) was used. DSC analysis was carried out in static nitrogen atmosphere at a temperature range of 20$600{ }^{\circ} \mathrm{C}$ with a flow rate of $40 \mathrm{ml} / \mathrm{min}$.

The elemental compositions of the pigments on the priming layer were identified by Laser Induced Breakdown Spectroscopy (LIBS) analysis on the painted surface. LIBS analyses were performed by measuring the spectral line intensities of the elements emitted from the plasma produced by a Q-switched $\mathrm{Nd}$ :YAG laser from a single laser pulse. Plasma emission was detected by an echelle type spectrograph (200-850 nm spectral range) equipped with an ICCD detector.

\section{Results and Discussion}

3.1. Physical and Raw Material Characteristics of the Rough and Fine Plaster Layers

Plasters on the walls of the Church are composed of a bottom and an upper layer. The bottom layer, which was applied over

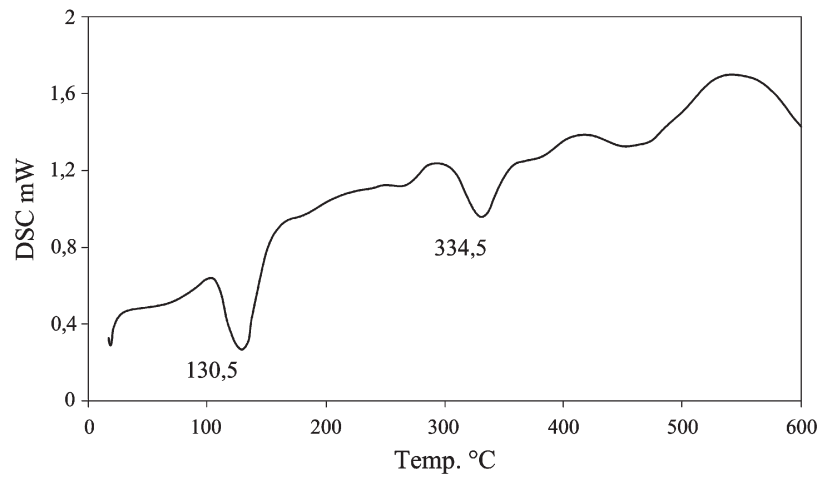

Fig. 6-DSC graph of binding media of paintings. the wall structure has a rough surface and non-uniform thickness. However, the upper layer has a fine, smooth surface and uniform thickness $(6 \mathrm{~mm})$.

The bottom layer is mainly composed of binder and natural aggregates with small amounts of oakum and straw pieces. Its density and porosity values are approximately $1.7 \mathrm{~g} / \mathrm{cm}^{3}$ and $33 \%$ by volume respectively. It is mainly composed of calcite, quartz, albite and feldspar minerals (Fig. 3). Calcite originates from the lime binder and the others from aggregates. The lime/aggregate ratio of the bottom plaster layer is nearly $1 / 3$ by weight. The aggregate sizes that ranged from $1180-500 \mu \mathrm{m}$ comprise the largest fraction of the total aggregates, and varied in the range of $61-73 \%$. Aggregates larger than $1180 \mu \mathrm{m}$ and smaller than $125 \mu \mathrm{m}$ made up the smallest fraction of the total aggregate. This shows that mostly fine and very fine aggregates were used in the preparation of the rough plaster.

The fine plaster layer is mainly composed of carbonated lime and the fine size of acid soluble aggregates (marble or limestone powder) with oakum and straw pieces. Oakum and straw pieces could be used in order to avoid crack formation during drying and carbonation of the lime [1]. Density and porosity values of the fine layers were about $1.4 \mathrm{~g} / \mathrm{cm}^{3}$ and $41 \%$ by volume respectively. XRD patterns of the fine plaster indicated that it was mainly composed of calcium carbonate $\left(\mathrm{CaCO}_{3}\right)$ and magnesium carbonate $\left(\mathrm{MgCO}_{3}\right)$ (Fig. 4). Considering the results, it could be claimed that the binder used in the preparation of plaster was lime containing magnesium hydroxide.

\subsection{Characteristics of the Painting Layers Applied on Fine Plaster}

SEM analysis indicated that the paintings were composed of binding and priming layers with pigments. Binding media has about $90-110 \mu \mathrm{m}$ thickness over the fine plaster and priming layer has about $12 \mu \mathrm{m}$ thickness over the binding layer. The thickness of the pigment layers was approximately $5 \mu \mathrm{m}$ on the priming layer (Fig. 5).

\subsubsection{Composition of Binding Layers}

The composition of the binding materials of the paintings was determined by SEM-EDS, FT-IR, DSC and TGA analysis.

In the DSC spectrum of the binding medium, phase changes were observed at about $130{ }^{\circ} \mathrm{C}$ and $335{ }^{\circ} \mathrm{C}$ due to melting and 


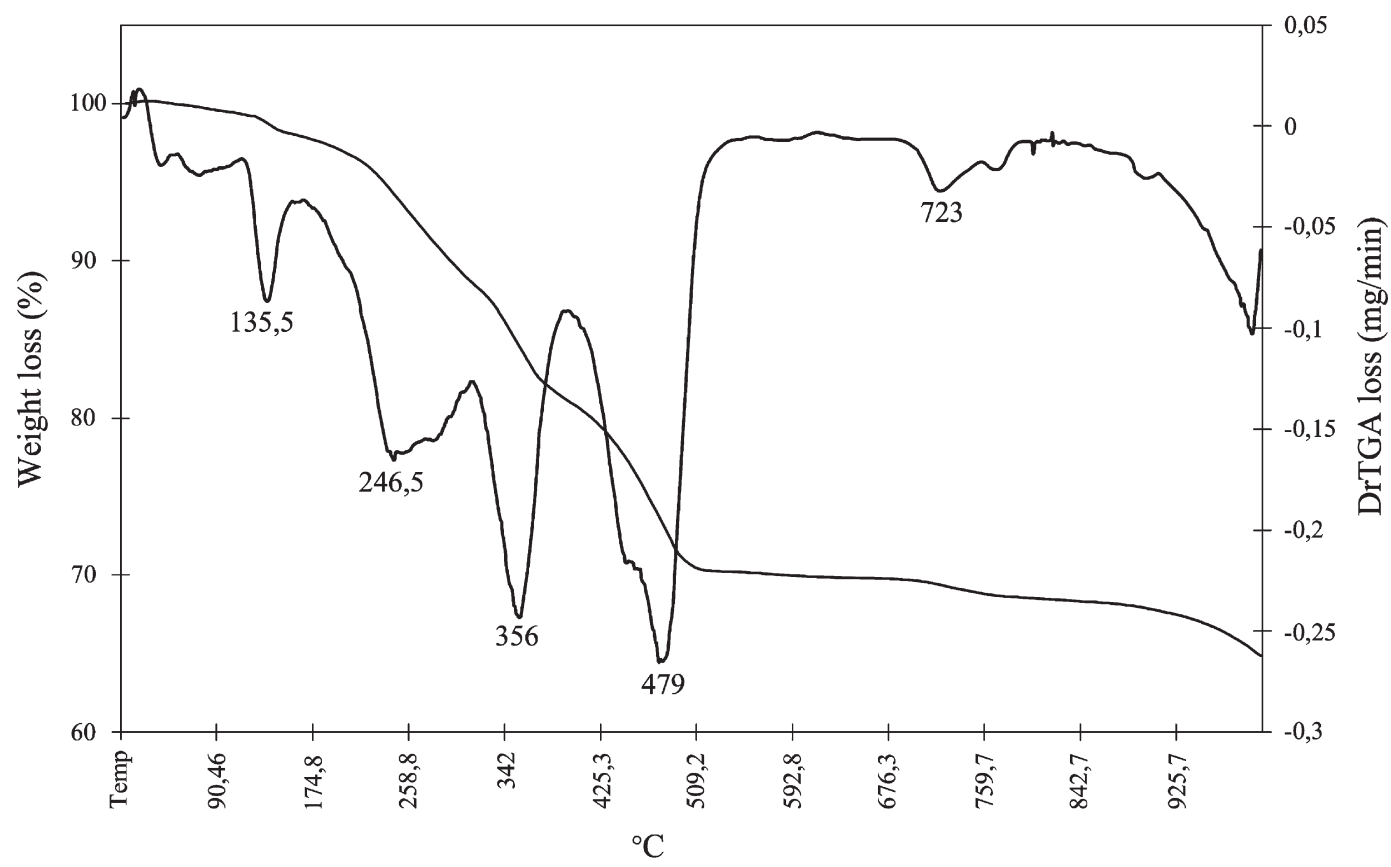

Fig. 7-TGA graph of binding media of paintings.

decomposition temperatures of the materials (Fig. 6). This result may indicate the presence of organic polymeric substances in the composition of the binding layer. In previous work, similar results have also been noted in the analyses of binding media that have been prepared by vegetable oil [8]. TGA analyses also support this result. In TGA graphs, weight losses are observed in the range of $30-200{ }^{\circ} \mathrm{C}, 200-600{ }^{\circ} \mathrm{C}$ and $600-900{ }^{\circ} \mathrm{C}$, which are mainly due to absorbed water, decomposition of organic matter and carbon dioxide, respectively. The weight loss of the sample within a temperature range from $30{ }^{\circ} \mathrm{C}$ to $200{ }^{\circ} \mathrm{C}$ is $3.01 \%$. The weight losses within a range from $200^{\circ} \mathrm{C}$ to $600^{\circ} \mathrm{C}$ and $600-900^{\circ} \mathrm{C}$ are $27.05 \%$ and $2.11 \%$, respectively (Fig. 7 ). The observation of high percentage loss at $200-600{ }^{\circ} \mathrm{C}$ shows the presence of high amount of organic matter in the binder. Weight losses at temperatures between 600 and $900{ }^{\circ} \mathrm{C}$ were due to carbon dioxide released during the decomposition of calcium carbonate, which was found as impurities in the binding layers.

The compositions of the binder were determined by FT-IR analyses. In the FT-IR spectrum, the main hydroxyl band $(\mathrm{OH})$ at $3410 \mathrm{~cm}^{-1}$, fatty acids $\left(\mathrm{CH}_{2}\right)$ at 2924 and $2854 \mathrm{~cm}^{-1}$, esters $(\mathrm{C}=\mathrm{O}) 1743 \mathrm{~cm}^{-1}$, oxalate $\left(\mathrm{C}_{2} \mathrm{O}_{4}^{-2}\right)$ at $1620 \mathrm{~cm}^{-1}$, carbonate $\left(\mathrm{CO}_{3}^{-2}\right)$ at 1419 and $875 \mathrm{~cm}^{-1}$ and sulphate $\left(\mathrm{SO}_{4}^{-2}\right)$ at $1118 \mathrm{~cm}^{-1}$ were observed (Fig. 8). Fatty acids, esters and oxalate bands have already been identified in the FT-IR spectrum of dried

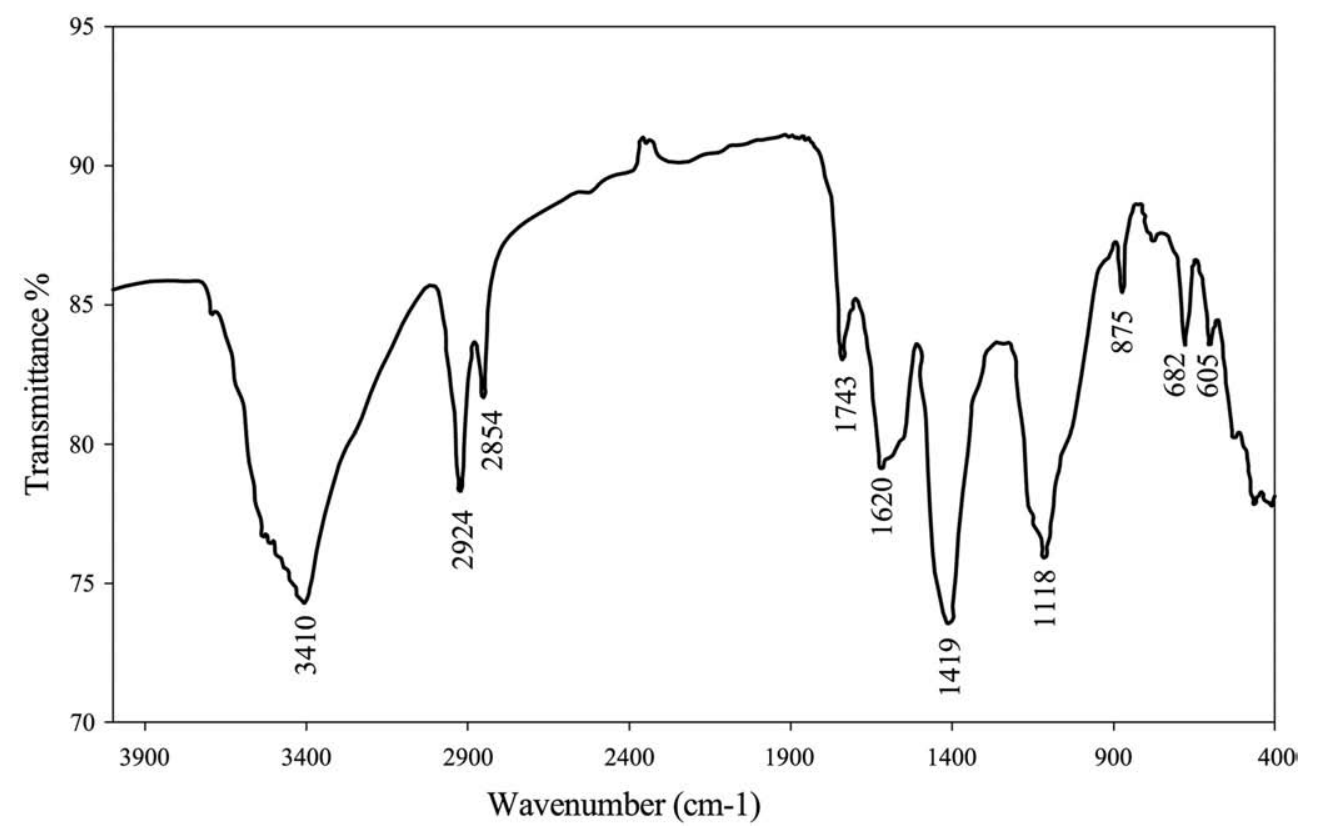

Fig. 8-FTIR spectrum of binding media of paintings. 
a)

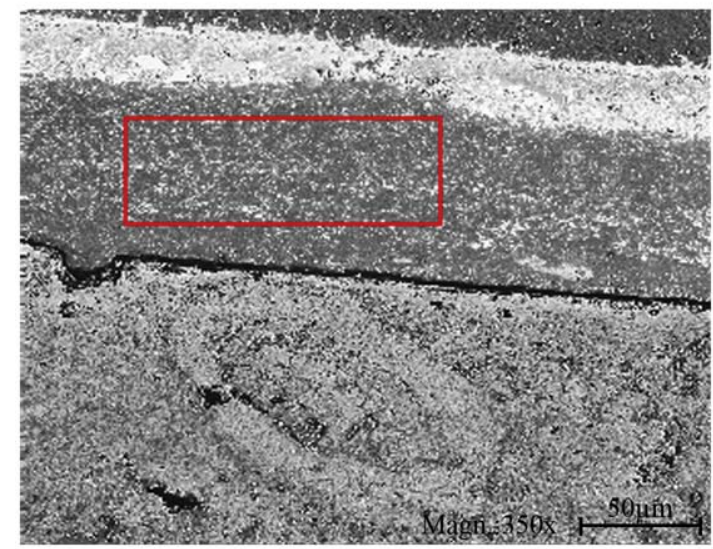

b)

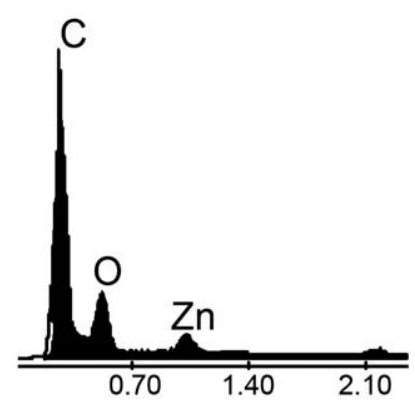

Fig. 9-SEM image (a) and EDX spectrum (b) of the binding layer of the paintings.

vegetable oils [16]. Sulphate and carbonate bands could originate from materials used in the preparation of priming layers and the binders of fine plasters.

Chemical compositions of the binder were determined by SEM-EDS analysis. SEM-EDS analyses of the binder indicated that it contains high amounts of carbon (C) and low amounts of zinc (Zn) (Fig. 9). The high amounts of carbon in its composition show that the binder was produced from organic compounds. The presence of zinc may be explained by the addition of zinc oxide as a catalyst for the polymerization reaction of binder that was mainly composed of vegetable oil [17]. a)

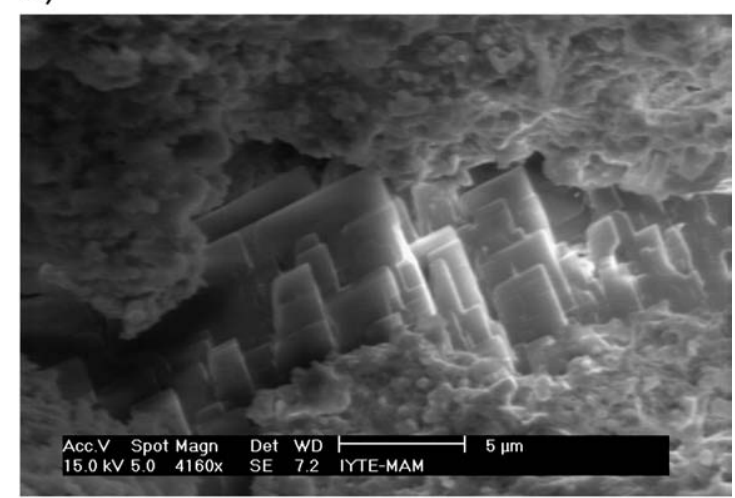

b)

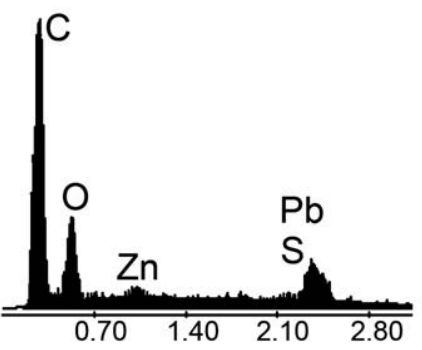

Fig. 11-SE image (a) and EDX spectrum (b) of anglesite crystals observed in the compositions of priming layer.

As a result of IR, DSC, TGA and SEM-EDS analyses of the binding media, it is considered that the binder of wall paintings was prepared by using drying oils, most probably from linseed oil.

\subsubsection{Mineralogical and Chemical Compositions of} Priming Layers

X-ray Diffraction analyses of the powdered painting layers showed that they were mainly composed of anglesite mineral $\left(\mathrm{PbSO}_{4}\right)$ (Fig. 10). In the SEM-EDS analysis, crystals composed of lead and sulphur were found (Fig. 11). These two results show the use of anglesite minerals in the preparation of the priming layers. In some early studies, a similar usage has already been noted $[2,18]$.

\subsubsection{Chemical Characteristics of Pigments}

LIBS analysis was carried out to identify the elemental compositions of the pigments. LIBS analysis of the brown painting

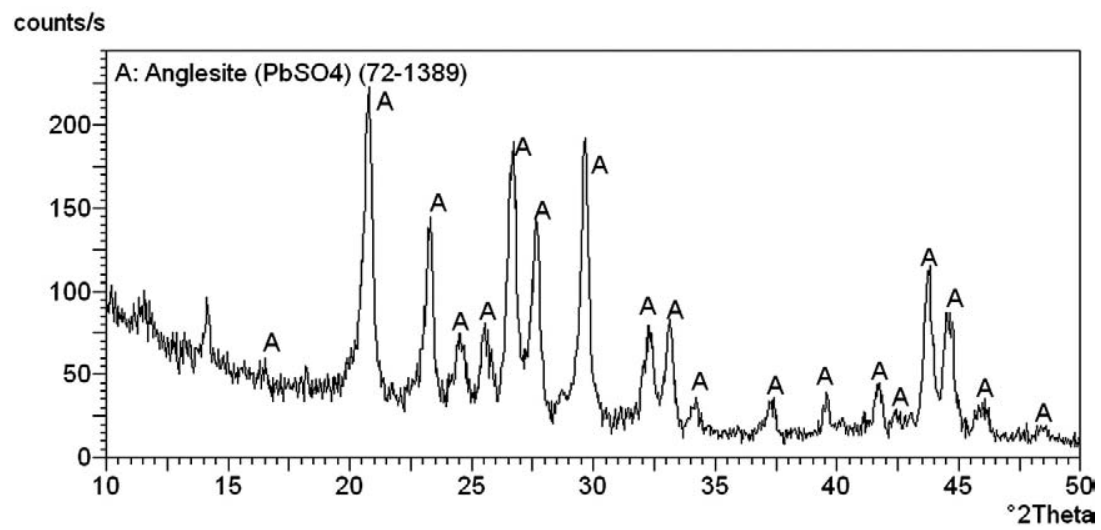

Fig. 10-XRD Pattern of priming layers of paintings. 


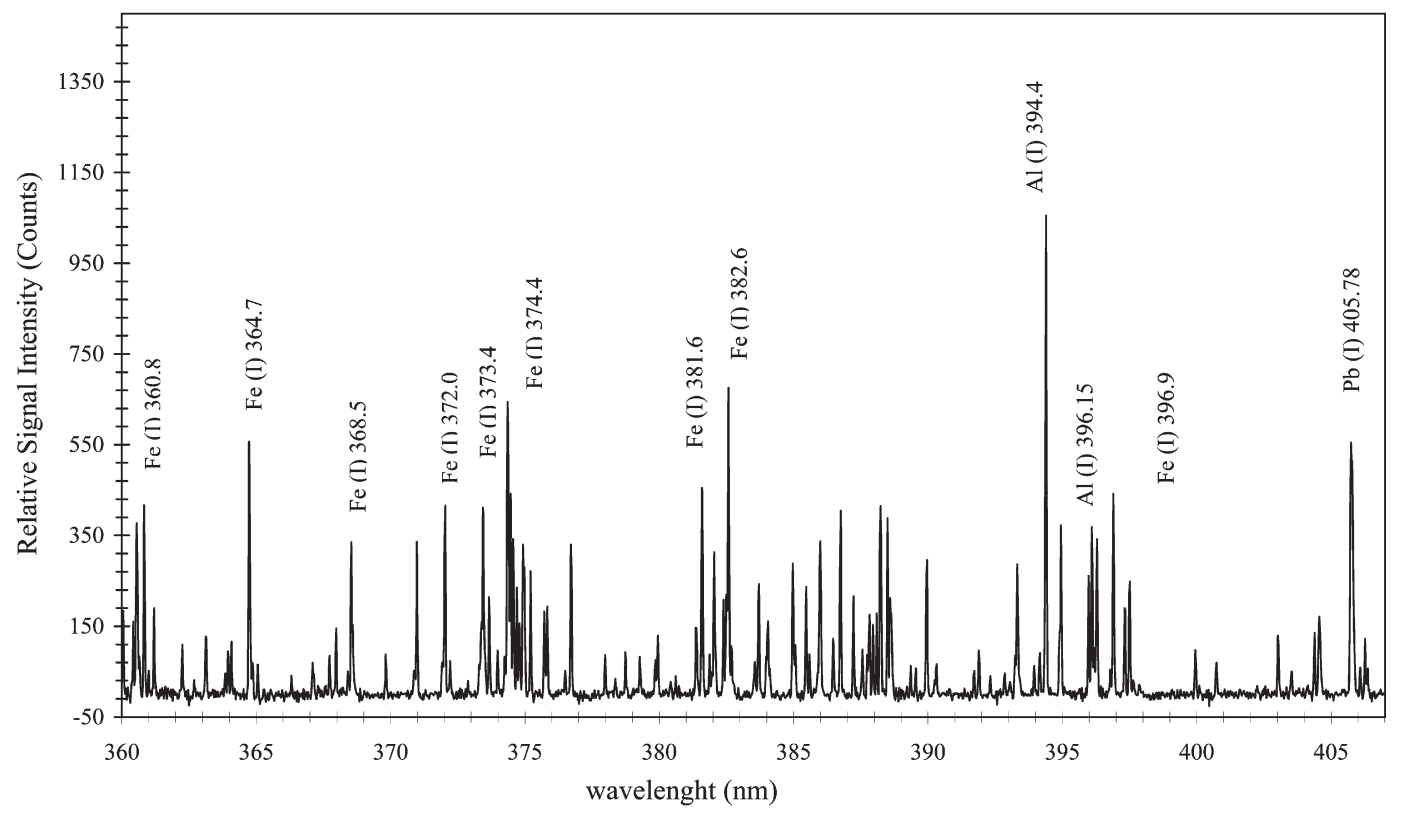

Fig. 12-LIBS spectrum of brown painting.

surfaces indicated the presence of iron (Fe), and lead (Pb) (Fig. 12). Specific emission lines of the elements observed in LIBS spectrum were labeled in units of nanometers, $\mathrm{nm}$. The presence of iron may show the use of iron containing pigments such as iron oxide $[17,18]$. The observation of unexpected lead signal can be explained due to impurities originating from the priming layer which was mainly composed of anglesite $\left(\mathrm{PbSO}_{4}\right)$.

In the LIBS analyses of the red colored painting surfaces, a strong signal of lead and chromium was detected (Fig. 13). This may show the use of chrome red $\left(\mathrm{PbCrO}_{4} . \mathrm{PbO}\right)$ as pigment [19].
The observation of Fe and Ca signals in the analysis can be explained by the lime and brown pigment impurities found on the red painting.

LIBS analysis of green painting surfaces showed the presence of $\mathrm{Na}, \mathrm{Mg}, \mathrm{Al}$ and $\mathrm{Fe}$ (Fig. 14). In previous studies, the use of celadonite and glauconite called "green earth" having the same elements has been noted as pigments $[17,18,20]$. The observation of similar elements found in the composition of green painting surface may indicate the use of "green earth" as pigment in the painting.

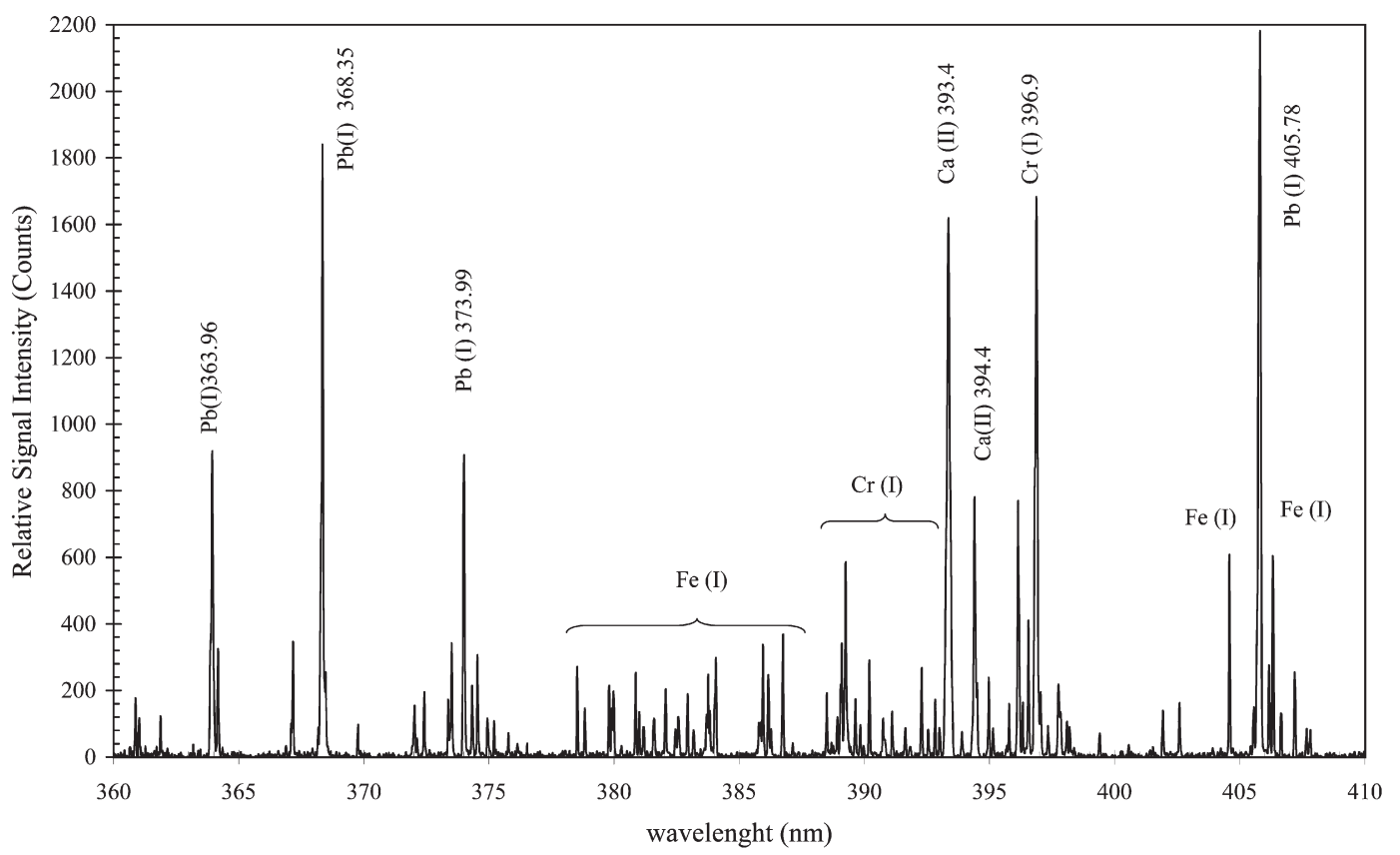

Fig. 13-LIBS spectrum of red painting. 


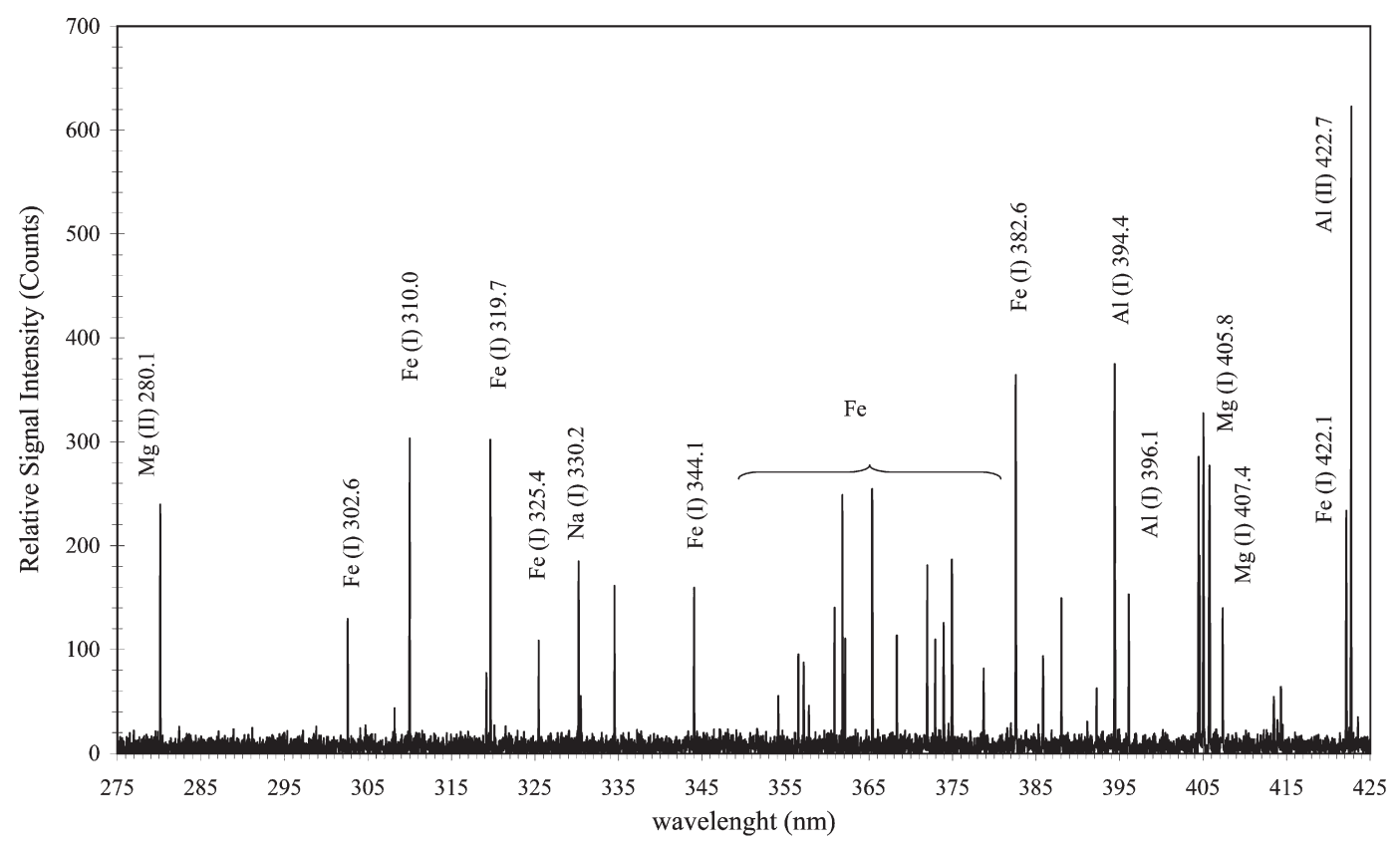

Fig. 14-LIBS spectrum of green painting.

\subsection{Deterioration Problems of the Wall Paintings}

The main deterioration phenomena observed on the wall paintings were disintegration of plaster layers, blistering and peeling of painted surfaces (Fig. 15). SEM analysis indicated that the adhesion between the binding and priming layers of

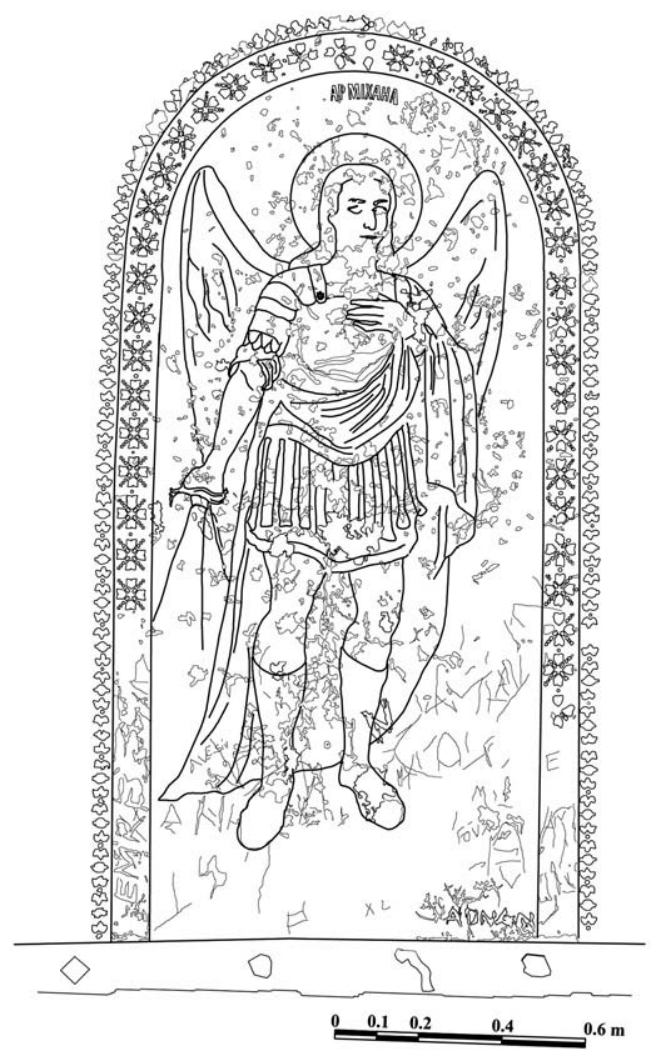

Fig. 15-Measured drawing of the Michael painting. paintings was diffuse and strong. However, the common problems were the formation of micro-cracks on the surface, blistering of priming layers (Figs. 16, 17) and the detachment of

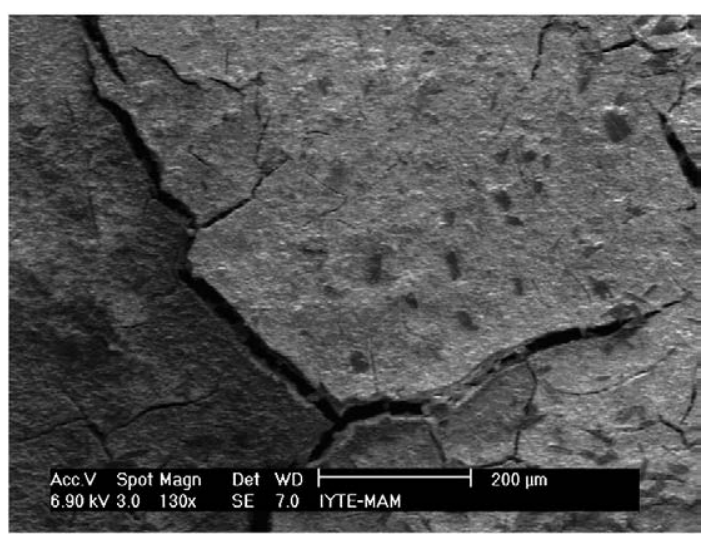

Fig. 16-SE image of micro crack formation on painting surface.

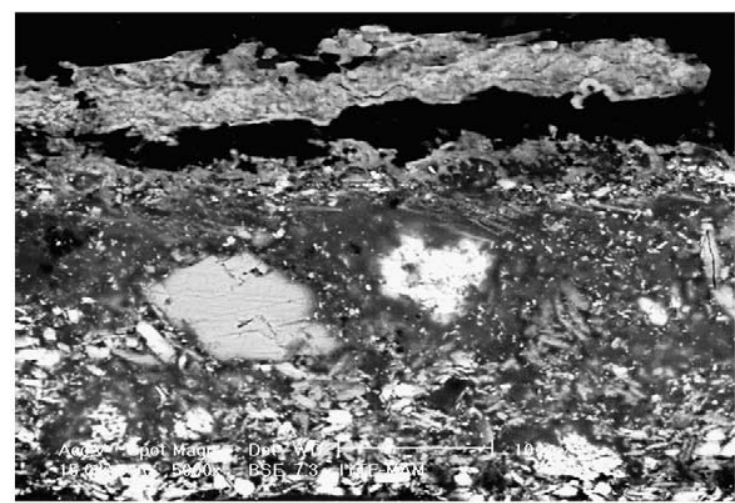

Fig. 17-BSE image of blistering on painting surface. 


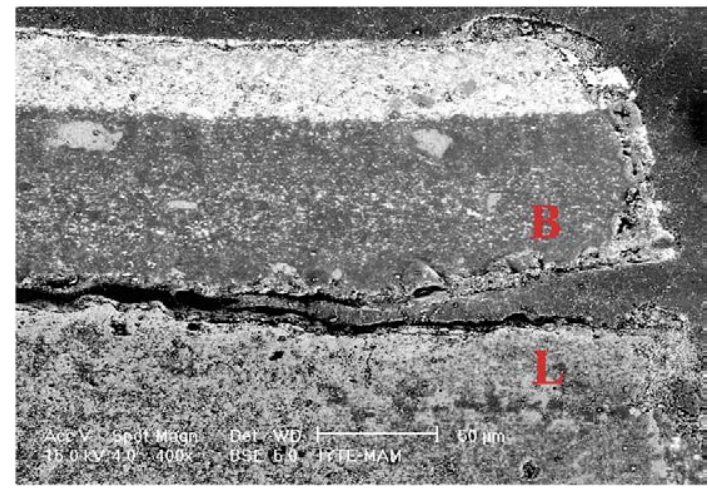

Fig. 18-BSE image of the detachment of painting layers from the lime plaster (B: binding layer, L: lime plaster).

the binding layer from the fine plasters (Fig. 18). Repeated wetting and drying cycles of the surfaces due to the rain penetration through the cracks or holes in the walls can be causes of the observed deteriorations on the paintings.

\section{Conclusion}

In this study, XRD, SEM, FT-IR, DSC, TGA and LIBS were used for the characterization of materials used in the execution of historic oil paintings in a 19th century church in Ayvalik/ Turkey. Oil paintings executed on the walls of this historic church are composed of very thin binding and white priming layers on which the pigments are applied. Binding layers are composed of vegetable oils with the addition of zinc oxide as a catalyst for their polymerization. Priming layers are mainly composed of lead white (anglesite $-\mathrm{PbSO}_{4}$ ) and vegetable oil. LIBS spectral measurements indicated that, the pigments used in wall paintings were red chrome, green earth and iron oxide. The main deterioration problems found in the wall paintings are the formation of micro-cracks on the surface, blistering of priming layers and the detachment of the binding layer from the fine plasters.

It is important to preserve wall paintings in situ. Restoration of paintings must be performed after the consolidation of the building. At first adhesion of painted plasters with support must be consolidated. A lime based grout can be used for this purpose. In interventions that will be carried out to cure micro-crack formation, blistering and detachment, linseed oil can be used as binder. Organic polymers were used in the execution of wall paintings. Thus, usage of organic solvents must be avoided in all of the interventions that will be conducted on these paintings.

\section{R E F E R E N C E S}

[1] Mora P, Mora L, Philippot P. Conservation of wall paintings. London: Butterworths; 1984.

[2] Van den Berg JDJ. Analytical chemical studies on traditional linseed oil paints, Ph.D. Thesis, Institute for Atomic and Molecular Physics (AMOLF), Amsterdam, Holand; 2002.

[3] Lang PL, Keefer CD, Juenemann JC, Tran KV, Peters SM, Huth NM, et al. The infrared microspectroscopic and energy dispersive $\mathrm{X}$-ray analysis of paints removed from a painted, medieval sculpture of Saint Wolfgang. Microchem J 2003;74:33-46.

[4] Barnett JR, Miller S, Pearce E. Colour and art: a brief history of pigments. Optic \& Laser Technology 2005;38:445-53.

[5] Surowiec I, Kaml I, Kenndler E. Analysis of drying oils used as binding media for objects of art by capillary electrophoresis with indirect UV and conductivity detection. J Chromatog A 2004;1-2:245-54.

[6] Perardi A, Zoppi A, Castellucci E. Micro-Raman spectroscopy for standard and in situ characterization of painting materials. J Cult Herit 2000;1(1):269-72.

[7] Edwards HGM, Brooke CJ, Tait JFK. Fourier transform Raman spectroscopic study of pigments from English mediaeval wall paintings. J Raman Spectrosc 1997;28:95-8.

[8] Prati S, Chiavari G, Cam D. DSC application in the conservation field. J Therm Anal Calorim 2001;66:315-27.

[9] Turri B, Vicini S, Margutti S, Pedemonte E. Calorimetric analyses of the polymerization process of linseed oil. J Therm Anal Calorim 2001;66:343-8.

[10] Gimeno-Adelantado JV, Mateo-Castro R, Doménech-Carbó MT, Bosch-Reig F, Doménech-Carbó A, Casas-Catalán MJ, et al. Identification of lipid binders in paintings by gas chromatography influence of the pigments. J Chromatogr A 2001;922:385-90.

[11] Brysbaert A, Melessenaki K, Anglos D. Pigment analysis in Bronze Age Aegean and Eastern Mediterranean painted plaster by laser-induced breakdown spectroscopy (LIBS). J Archaeol Sci 2006;33:1095-104.

[12] Anglos D, Couris S, Fotakis C. Laser Diagnostics of painted artworks: Laser Induced Breakdown Spectroscopy of pigments. Appl Spectrosc 1997;51:1025-30.

[13] Anglos D. Laser Induced Breakdown Spectroscopy in art and archaeology. Appl Spectrosc 2001;55:186A-205A.

[14] Turgut AÖ. Ayvalık kilise ve manastırları, B.A. Thesis, Ege University, İzmir, Turkey; 1996.

[15] RILEM. Tests defining the structure. Mater Const 1980;13:73.

[16] Van der Weerd J. Microspectroscopic analysis of traditional oil paint, Ph.D. Thesis, Institute for Atomic and Molecular Physics (AMOLF), Amsterdam, Holand; 2002.

[17] Harley RD. Artists' pigments c.1600-1835. London: Archetype Publications; 2001.

[18] Clark RJH. Pigment identification by spectroscopic means: an arts/science interface. Acad Sci 2002;5:7-20.

[19] Bell IM, Clark RJH, Gibbs PJ. Raman spectroscopic library of natural and synthetic pigments. Spectrochim Acta Part A 1997;53:2159-79.

[20] Hradil D, Grygar T, Hradilová J, Bezdićka P. Clay and iron oxide pigments in the history of painting. Appl Clay Sci 2003;22:223-36. 